\title{
Metal Contents in Fish from the Bay of Bengal and Potential Consumer Exposure-The EAF-Nansen Programme
}

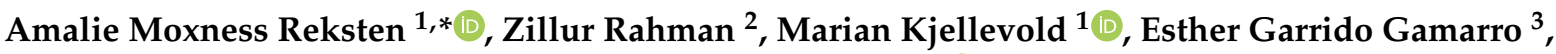 \\ Shakuntala H. Thilsted ${ }^{4}$, Lauren M. Pincus ${ }^{4}$, Inger Aakre ${ }^{1}{ }^{\circledR}$, John Ryder ${ }^{3}$, Sujeewa Ariyawansa ${ }^{5}$, \\ Anna Nordhagen ${ }^{1}$ and Anne-Katrine Lundebye ${ }^{1}$ \\ 1 Seafood, Nutrition and Environmental State, Institute of Marine Research, P.O. Box 2029 Nordnes, \\ 5817 Bergen, Norway; marian.kjellevold@hi.no (M.K.); inger.aakre@hi.no (I.A.); \\ nordhagen_94@hotmail.com (A.N.); anne-katrine.lundebye@hi.no (A.-K.L.) \\ 2 Quality Control Laboratory, Department of Fisheries, Ministry of Fisheries \& Livestock, \\ Khulna 9000, Bangladesh; zrahmantec@gmail.com \\ 3 Fisheries and Aquaculture Department, Food and Agriculture Organisation of the United Nations (FAO), \\ 00153 Rome, Italy; esther.garridogamarro@fao.org (E.G.G.); john.ryder@fao.org (J.R.) \\ 4 WorldFish, Jalan Batu Maung, Batu Maung, Bayan Lepas 11960, Penang, Malaysia; \\ s.thilsted@cgiar.org (S.H.T.); L.Pincus@cgiar.org (L.M.P.) \\ 5 National Aquatic Resources Research and Development Agency, Crow Island, Colombo 01500, Sri Lanka; \\ sujeewa@nara.ac.lk \\ * Correspondence: amalie.moxness.reksten@hi.no; Tel.: +47-975-83-296
}

check for updates

Citation: Moxness Reksten, A.; Rahman, Z.; Kjellevold, M.; Garrido Gamarro, E.; Thilsted, S.H.; Pincus,

L.M.; Aakre, I.; Ryder, J.; Ariyawansa, S.; Nordhagen, A.; et al. Metal Contents in Fish from the Bay of Bengal and Potential Consumer Exposure-The EAF-Nansen Programme. Foods 2021, 10, 1147. https://doi.org/10.3390/foods10051147

Academic Editor: Ángel

José Gutiérrez Fernández

Received: 13 April 2021

Accepted: 19 May 2021

Published: 20 May 2021

Publisher's Note: MDPI stays neutral with regard to jurisdictional claims in published maps and institutional affiliations.

Copyright: (c) FAO 2021 CC BY NC SA IGO 3.0. Submitted for possible open access publication under the terms and conditions of the Creative Commons Attribution (CC BY) license (https://creativecommons.org/licenses/by/4.0/).
Abstract: Fish represent an important part of the Sri Lankan and Bangladeshi diet. However, fish is also a source of contaminants that may constitute a health risk to consumers. The aim of this study was to analyse the contents of arsenic, cadmium, mercury, and lead in 24 commonly consumed marine fish species from the Bay of Bengal and to assess the potential health risk associated with their consumption. Mercury and lead contents did not exceed the maximum limits for any of the sampled species, and consumer exposure from estimated daily consumption was assessed to be minimal for adults and children. Numerous samples exceeded the maximum limit for cadmium $(58 \%)$, particularly those of small size $(\leq 25 \mathrm{~cm})$. However, consumer exposure was insignificant, and health assessment showed no risk connected to consumption. These data represent an important contribution to future risk/benefit assessments related to the consumption of fish.

Keywords: arsenic; cadmium; mercury; lead; Bangladesh; Sri Lanka; fish; risk assessment

\section{Introduction}

Fish represent an important and rich source of essential and bioavailable nutrients, such as long-chain polyunsaturated fatty acids, protein, vitamin $A$, vitamin $B_{12}$, vitamin $D$, calcium, iodine, and selenium [1,2]. We have previously shown that several of the marine fish species from Sri Lanka and Bangladesh may provide $25 \%$ or more of the recommended daily nutrient intake for multiple micronutrients [3,4]. In Sri Lanka, fish is estimated to contribute to approximately $55 \%$ of total animal protein intake per capita [5], whereas, in Bangladesh, the contribution is estimated to be around 60\% [6]; thus, fish is the most important animal source of food in both countries [7]. However, fish may also be a source of various contaminants, such as metals, persistent organic pollutants (POPs), and plastics. Metal pollution of the aquatic environment may derive from anthropogenic activities, such as industrial processes and industrial waste, mining and smelting operations, and domestic and agricultural use of metals and metal-containing compounds, as well as a result of natural phenomena, such as volcanic eruptions and weathering [8-11]. As developing countries, both Sri Lanka and Bangladesh are at higher risk of metal pollution of the aquatic environment as a consequence of rapid urbanisation and industrialisation [12-14]. Heavy metals (such as cadmium, mercury, and lead) and metalloids (such as arsenic), 
hereafter combined and referred to as "metals", readily bioaccumulate in the food chain and are characterised by a high level of human toxicity, even at low concentrations. Due to their long persistence in the environment, they rank among the top five priority metals that are of public health significance in the world today [11,15]. These metals are all classified as either "known" or "probable" human carcinogens, and exposure is associated with a host of negative health outcomes, including renal, skeletal, cardiovascular, and neurological damage, diminished cognitive function, developmental anomalies in children, and mortality at high concentrations $[10,15,16]$.

To ensure harmonisation between the fisheries sector and various food safety standards, several guidelines, guidance documents, and regulations for risk management at national, regional, and international levels have been established. For example, The Codex Alimentarius Commission is a food standard setting body that constitutes a central part of the Joint Food and Agriculture Organisation (FAO)/World Health Organisation (WHO) Food Standards Programme that was established by FAO and WHO to protect consumers' health and promote fair practices in food trade. Maximum exposure levels delineate a consumption threshold above which consumers are likely to be adversely exposed to various contaminants and are specific for each metal in various food products. Fish and fish products intended for export are subject to strict export regulations; in Sri Lanka and Bangladesh, local export regulations are based primarily on European Union (EU) legislation as the EU, Japan, and the United States of America (USA) are the three top destinations for fisheries exports from both countries [13,17,18].

Fish consumption is one of the major routes of arsenic, cadmium, mercury, and lead exposure to humans $[19,20]$. Fish concentrate mercury as the highly toxic form of organic methylmercury $(\mathrm{MeHg})$, either transformed from inorganic mercury in the aquatic environment by anaerobic bacteria (methylation) or through feed components such as plankton and small fish in the aquatic food chain [20-22]. EU legislation has established maximum permissible levels for cadmium $(0.050 \mathrm{mg} / \mathrm{kg}$ wet weight (w.w.)), mercury $(0.5 \mathrm{mg} / \mathrm{kg} \mathrm{w.w.)}$, and lead (0.3 mg/kg w.w.), but not for arsenic (Table 1) [23]. The maximum limit for lead in fish is in line with the guidelines provided by The Codex Alimentarius in its General Standard for Contaminants and Toxins in Food and Feed (CXS 193-1995). The Codex Alimentarius Commission has not established a maximum limit for mercury in fish; however, a level of $0.5 \mathrm{mg} / \mathrm{kg}$ w.w. has been established for $\mathrm{MeHg}$, which is similar to the level established for total mercury by the EU [24]. For arsenic compounds in fish, no maximum content has yet been established. Fish is a major source of total arsenic exposure, but the majority of the arsenic is in the form of organic arsenic, specifically arsenobetaine, which is virtually nontoxic $[19,21]$.

Table 1. Maximum limits and tolerable weekly intakes for contaminants in muscle fillet of fish for arsenic (As), cadmium $(\mathrm{Cd})$, mercury $(\mathrm{Hg})$, and lead $(\mathrm{Pb})$.

\begin{tabular}{ccc}
\hline Metal & $\begin{array}{c}\text { Maximum Limit } \\
(\mathbf{m g} / \mathbf{k g} \text { w.w.) }\end{array}$ & $\begin{array}{c}\text { Provisional Tolerable Weekly } \\
\text { Intake (PTWI) }\end{array}$ \\
\hline Arsenic $(\mathrm{As})$ & $-^{\mathrm{a}}$ & $-\mathrm{b}$ \\
Cadmium $(\mathrm{Cd})$ & $0.050^{\mathrm{c}}$ & PTMI: $25 \mu \mathrm{gg} / \mathrm{kg} \mathrm{b.w.} \mathrm{d}$ \\
Mercury $(\mathrm{Hg})$ & $0.50^{\mathrm{c}, \mathrm{e}, \mathrm{f}}$ & $1.6 \mu \mathrm{\mu g} / \mathrm{kg} \mathrm{b.w.} \mathrm{s}$ \\
Lead $(\mathrm{Pb})$ & $0.30^{\mathrm{c}, \mathrm{e}}$ & $-\mathrm{b}$ \\
\hline
\end{tabular}

a No maximum limit established for arsenic in fish or other seafood. ${ }^{\mathrm{b}}$ PTWI withdrawn by the Joint FAO/WHO Expert Committee on Food Additives (JECFA) due to no longer being considered health-protective. ${ }^{c}$ European Union, Commission Regulation (EC) 488/2014 [25]. The EU maximum limit for cadmium is $0.050 \mathrm{mg} / \mathrm{kg}$ for most species, but is $0.1,0.15$, and $0.25 \mathrm{mg} / \mathrm{kg}$ for certain species. ${ }^{\mathrm{d}}$ Due to the long half-life of cadmium, the JECFA determined that indicating the tolerable intake monthly is more appropriate than weekly; thus, the PTMI value


Codex Alimentarius is for methylmercury $(\mathrm{MeHg}) .{ }^{\mathrm{f}}$ Certain predatory fish species of high trophic levels are excluded and possess a higher maximum limit of $1 \mathrm{mg} / \mathrm{kg}$ muscle [23,24]. ${ }^{\mathrm{g}}$ The PTWI is given for MeHg, as this is the form most commonly found in fish and seafood [20-22,26]. Abbreviations: b.w.: body weight; JECFA: Joint FAO/WHO Expert Committee on Food Additives; PTMI: provisional tolerable monthly intake; w.w.: wet weight. 
Because dietary intake of fish is a major mechanism of human exposure to these metals compared to other routes such as inhalation and dermal contact $[15,18]$, regular monitoring of concentrations in fish and seafood and knowledge of seafood consumption are essential. The Joint FAO/WHO Expert Committee on Food Additives (JECFA) is an international expert committee administered jointly by the FAO and WHO that carries out risk assessments for food additives (intentionally added), natural toxins, and contaminants among others. The JECFA has established provisional tolerable weekly intake (PTWI) levels for contaminants, which sets limits for the maximum intake of contaminants in food that may be consumed weekly over a lifetime, without causing any adverse health effects. The term "tolerable" is used to signal permissibility rather than acceptability of the intake of contaminants inevitably associated with the intake of various foods, and the value is given on a weekly basis to allow for daily variations in intake. To express the cautious nature of the evaluation, the term "provisional" is used to signify the dynamic nature of the values; new data on the health impacts of human exposure to these metals may change the PTWI levels if deemed necessary by the committee [27]. In 2010, the JECFA recommended that expressing the tolerable intake of cadmium monthly would be more appropriate than indicating it weekly, considering the metal's long half-life. Thus, the maximum safe cadmium intake is now set as a tolerable monthly intake of $25 \mu \mathrm{g} / \mathrm{kg}$ body weight (b.w.) [28]. For mercury, the JECFA has established two PTWI values: one applicable for dietary exposure from foods other than fish and seafood (inorganic mercury at $4 \mu \mathrm{g} / \mathrm{kg}$ b.w.) and the other for fish and seafood products ( $\mathrm{MeHg}$ at $1.6 \mu \mathrm{g} / \mathrm{kg} \mathrm{b.w.)}$ [29]. The PTWI for lead was revised from $0.05 \mathrm{mg} / \mathrm{kg}$ b.w. to $0.025 \mathrm{mg} / \mathrm{kg}$ b.w. in 1993; however, in 2010, the JECFA confirmed that lead exposure is associated with an increase in systolic blood pressure in adults and impaired neurodevelopment in children. Thus, it was concluded that the PTWI could no longer be considered health-protective and, therefore, the value was withdrawn. No new PTWI value for lead has been established [28]. Similarly, for arsenic, the previously established PTWI of $15 \mu \mathrm{g} / \mathrm{kg}$ b.w. was withdrawn in 2011 when the JECFA determined the lower limit of the benchmark dose for a $0.5 \%$ increased incidence of lung cancer $\left(\mathrm{BMDL}_{0.5}\right)$ to be in the region of the PTWI value and, therefore, no longer appropriate. Since then, no new PTWI value for arsenic has been established [30].

The Bay of Bengal occupies the north-eastern end of the Indian Ocean and borders India to the west, Sri Lanka and Indonesia to the south, Myanmar to the east, and Bangladesh to the north. The water body is recognised as highly dynamic and ecologically diverse. Major sources of marine pollution in the Bay of Bengal include industrial, agrochemical, and municipal wastes, in addition to oil pollution. Furthermore, the many large rivers flowing into the Bay of Bengal, including the Ganges, the Mahanadi, and the Krishna, are substantial carriers of domestic and industrial waste into the coastal and marine waters in the Bay, as proper waste disposal facilities are lacking in the surrounding countries [13,31]. Because many fish species occupy high trophic levels in the food chain, they are considered good bioindicators of pollutants in the aquatic environment and represent a good monitoring tool to assess changes in the environment [32-34]. However, information on metal contamination in numerous marine fish species found in the Bay of Bengal is limited, and research is needed to ensure that fish consumption does not pose a risk to consumer health. The aim of this study was, therefore, to investigate the presence of arsenic, cadmium, mercury, and lead in commonly consumed marine fish species, as well as two mesopelagic fish species from Sri Lanka and Bangladesh, to ascertain whether the contents were compliant with the maximum limits defined by legislations. Furthermore, the potential human exposure and potential health risks of these fish species, based on consumption rates in Sri Lanka and Bangladesh, were assessed.

\section{Materials and Methods}

This paper uses data collected through scientific surveys with the research vessel (R/V) Dr. Fridtjof Nansen as part of the collaboration among the EAF-Nansen Programme, the National Aquatic Resources Research and Development Agency (NARA) in Sri Lanka, 
and the Department of Fisheries (DoF) in Bangladesh. The EAF-Nansen Programme is a partnership among the FAO, the Norwegian Agency for Development Cooperation (Norad), and the Institute of Marine Research (IMR), Bergen, Norway, for sustainable management of the fisheries of partner countries.

\subsection{Sampling}

Sampling of fish was conducted during surveys with R/V Dr. Fridtjof Nansen in the Bay of Bengal. The Sri Lanka survey was conducted from 24 June to 15 July 2018, and the Bangladesh survey was conducted from 3 to 15 August 2018. Sampling was carried out using pelagic (MultiPelt 624 trawl) and bottom trawls (Gisund Super bottom trawl), and the catch was subsequently sorted and identified according to species by taxonomists. Fish species were selected for sampling on the basis of their importance to the respective local diets as commonly consumed marine fish species, and the selection of species was advised by Sri Lankan and Bangladeshi marine and food scientists on board the vessel. Mesopelagic species were also included in the study due to the limited knowledge on the chemical composition of such species, even though they are currently not commonly consumed. The length $(\mathrm{cm})$ of the fish from the tip of the head to the deepest fork of the caudal fin was measured, and the fish was weighed $(\mathrm{g})$ on a marine measuring board. The fish were then categorised as either small fish $(<25 \mathrm{~cm})$ or large fish $(>25 \mathrm{~cm})$. Samples of fish were prepared according to the consumption style in local diets, as advised by the local scientists on board: as whole fish, including the skin, bones, and viscera, as fillets with skin and intramuscular bones, or as fillets only (excluding the skin, bones, and viscera of the fish) (Table 2). The categorisations of the fish (small or large) corresponded to the local eating practice of the fish sampled from Sri Lanka, where all small fish are commonly consumed whole, and only the fillets of large fish are commonly consumed. For the fish species sampled from Bangladesh, all samples of commonly consumed fish are eaten as fillets with skin and bones, and, as very few species were longer than $25 \mathrm{~cm}$, all fish were categorised as "small". The mesopelagic species were prepared whole, including the head, skin, tail, and viscera. Three composite samples of each species, consisting of five randomly selected individuals in each sample for large fish and a minimum of 20 randomly selected individuals for small fish ( $n$ was dependent on the total biomass of the species in order to obtain an adequate sample weight for the analyses), were prepared for contaminant analyses at the IMR. The samples were first minced and homogenised, using a food processor (Braun Multiquick 7 K3000, Kronberg im Taunus, Germany), and stored as wet samples at $-20{ }^{\circ} \mathrm{C}$ in the freezer onboard the vessel. After a minimum of $12 \mathrm{~h}$ in the freezer, a subsample of each wet sample was freeze-dried for $72 \mathrm{~h}(24 \mathrm{~h}$ at $-50{ }^{\circ} \mathrm{C}$, immediately followed by $48 \mathrm{~h}$ at $+25^{\circ} \mathrm{C}$, with a vacuum of $0.2-0.01 \mathrm{mbar}$, Labconco Freezone 18 L mod. 7750306, Kansas City, USA), and the dry matter was calculated on the basis of the weight change upon entering and exiting the freeze-dryer. Freeze-dried samples were then homogenised to fine powder using a knife mill (Retch Grindomix GM 200, Haan, Germany). The freeze-dried samples were vacuum-sealed and stored in insulated boxes in the vessel's freezer at $-20^{\circ} \mathrm{C}$ until shipment by air cargo to the IMR laboratories, where the samples were stored at $-80^{\circ} \mathrm{C}$, pending analyses.

\subsection{Analytical Methods}

Metal analyses were performed at the IMR laboratories. The laboratories regularly participate in national and international proficiency tests with satisfactory results to check the accuracy and precision of the analyses. The analyses were performed using accredited methods according to ISO 17025:2005, and Certified Reference Materials (CRM) were included in each sample run for quality control (CRM 1556b, oyster tissue, National Institute of Standards and Technology, Gaithersburg, USA and TORT-3, Lobster Hepatopancreas Reference Material for Trace Metals, National Research Council, Ottawa, ON, Canada). All values were within the accepted range of the analyses and gave a mean accuracy of $104 \%$ for arsenic, $99 \%$ for cadmium, $84 \%$ for mercury, and $82 \%$ for lead. The contents of 
arsenic, cadmium, mercury, and lead were determined in a total of 93 composite samples (three samples for each fish species) which were both homogenised and freeze-dried. Detailed information regarding the analytical methods performed, including limits of quantification (LOQ) and the measurement uncertainty for each metal, were described by Reksten et al. [35].

Table 2. Overview of species sampled, tissue, number of composite samples, and number of fish in each composite sample.

\begin{tabular}{|c|c|c|c|}
\hline Scientific Name & Tissue Sampled & $\begin{array}{c}\text { Number of Composite } \\
\text { Samples }\end{array}$ & $\begin{array}{l}\text { Number of Fish in Each } \\
\text { Composite Sample }\end{array}$ \\
\hline \multicolumn{4}{|l|}{ Fish from Sri Lanka } \\
\hline \multicolumn{4}{|l|}{ Small fish } \\
\hline Amblygaster sirm & Whole fish & 3 & 25 \\
\hline Auxis thazard & Whole fish & 3 & 25 \\
\hline Decapterus macrosoma ${ }^{1}$ & Whole fish & 3 & 25 \\
\hline Decapterus macrosoma $^{2}$ & Whole fish & 3 & 25 \\
\hline Encrasicholina devisi & Whole fish & 3 & 50 \\
\hline Equulites elongates & Whole fish & 3 & 25 \\
\hline Leiognathus dussumieri & Whole fish & 3 & 25 \\
\hline Photopectoralis bindus 1 & Whole fish & 3 & 25 \\
\hline Photopectoralis bindus ${ }^{2}$ & Whole fish & 3 & 25 \\
\hline Rastrelliger kanagurta & Whole fish & 3 & 25 \\
\hline Sillago ingenuиa & Whole fish & 3 & 25 \\
\hline Stolephorus indicus & Whole fish & 3 & 25 \\
\hline \multicolumn{4}{|l|}{ Large fish } \\
\hline Carangoides fulvoguttatus & Fillet & 3 & 5 \\
\hline Diagramma pictum & Fillet & 3 & 5 \\
\hline Lethrinus olivaceus & Fillet & 3 & 5 \\
\hline Lutjanus lutjanus & Fillet & 3 & 5 \\
\hline Nemipterus bipunctatus & Fillet & 3 & 5 \\
\hline Selar crumenophthalmus & Fillet & 3 & 5 \\
\hline Sphyraena jello & Fillet & 3 & 5 \\
\hline \multicolumn{4}{|l|}{ Fish from Bangladesh ${ }^{a}$} \\
\hline Benthosema fibulatum & Whole fish & 3 & 250 \\
\hline Bregmaceros mcclellandi & Whole fish & 3 & 280 \\
\hline Dussumieria elopsoides ${ }^{1}$ & Fillet with skin and bones & 3 & 25 \\
\hline Dussumieria elopsoides 2 & Fillet with skin and bones & 3 & 25 \\
\hline Dussumieria elopsoides 3 & Fillet with skin and bones & 3 & $23^{b}$ \\
\hline Harpadon nehereus ${ }^{1}$ & Fillet with skin and bones & 3 & 25 \\
\hline Harpadon nehereus ${ }^{2}$ & Fillet with skin and bones & 3 & 20 \\
\hline Megalaspis cordyla & Fillet with skin and bones & 3 & 5 \\
\hline Pentaprion longimanus & Fillet with skin and bones & 3 & 25 \\
\hline Sardinella fimbriata ${ }^{1}$ & Fillet with skin and bones & 3 & $23^{b}$ \\
\hline Sardinella fimbriata ${ }^{2}$ & Fillet with skin and bones & 3 & 25 \\
\hline Sardinella fimbriata ${ }^{3}$ & Fillet with skin and bones & 3 & 25 \\
\hline
\end{tabular}

\subsection{Data Management and Presentation of Analytical Data}

The analytical data were exported from Laboratory Information Management System (LIMS) to Microsoft ${ }^{\circledR}$ Office 365 Excel version 1910 for calculations of means and standard deviations (SD). All values are presented as means \pm SD expressed in $\mathrm{mg} / \mathrm{kg}$ w.w. of the three composite samples consisting of $n$ individuals for each fish species. Statistical analyses were performed and graphs compiled using GraphPad Prism 8.3.0. The data did not meet the assumption of normality (tested using D'Agostino-Pearson normality test and Shapiro-Wilk normality test); thus, differences were considered significant by Mann-Whitney $t$-tests (nonparametric) when $p<0.05$. Correlation analysis (Spearman) 
was used to compare the mean length of the species to the cadmium and mercury contents of each composite sample. For individual samples presenting analysed values $<$ LOQ, a precautionary and conservative approach was used, assuming that the total amount of the contaminant present in the sample is equivalent to the LOQ value (upper bound LOQ). Thus, the unadjusted LOQ value was used when calculating the mean and SD of each species. For cadmium, four of 93 measurements were below the LOQ, whereas, for lead, 39 of 93 measurements (all samples of large species from Sri Lanka) were below the LOQ. For arsenic, no values were below the LOQ, whereas, for mercury, two of 93 measurements were below the LOQ. The content of mercury was measured as total mercury in this study; it can be assumed that $80-100 \%$ of the total mercury in fish is in the form of $\mathrm{MeHg}[26,30]$. Similarly, the content of arsenic was measured as the total content of all arsenic compounds present in the samples.

\subsection{Consumer Exposure}

A preliminary estimation of the potential risk to human health related to cadmium and mercury exposure through fish consumption was established by evaluating the estimated daily intake of fish compared to the PTWI. This was determined on the basis of the average contents of metals in fish tissue and the average daily fish consumption rates. The values were presented as the percentage of the PTWI and PTMI values for MeHg and cadmium, respectively, as provided by the JECFA. For the exposure assessment of mercury, a precautionary approach was applied assuming that the total mercury in fish was entirely in the form of MeHg [36-40]. For cadmium, the values were calculated assuming a fish intake of four times per month (one time per week) for each fish species. The calculations were not performed for arsenic and lead as no PTWI values are available for these metals. The consumer exposure estimation was performed for both an average South Asian adult of $60 \mathrm{~kg}$ and a 10 year old child of $27 \mathrm{~kg}$ [41-43]. A daily Sri Lankan serving size of fish was estimated to be $43 \mathrm{~g}$, according to the Household Income and Expenditure Survey (HIES) report from 2016 [44,45]. For Bangladesh, fish consumption was assumed to be higher at $54 \mathrm{~g}$ /day according to the HIES from 1991, 2000, and 2010 [46]. Due to the unavailability of intake rates for different age groups, an intake of $60 \%$ of that of an adult was assumed for children.

\subsection{Health Risk Assessment}

The methodology for estimation of noncarcinogenic risks and carcinogenic risks was applied in accordance with the methodology provided by the United States Environmental Protection Agency (US EPA) Region III's Risk-Based Concentration Table [47]. For the calculations, we assumed that processing and cooking have no effect on the toxicity nor the contents of metals in fish, and the ingestion dose was assumed to be equal to the metal content.

\subsubsection{Noncarcinogenic Exposure}

The noncarcinogenic risk for each metal through fish consumption was assessed using the target hazard quotient (THQ) [47], which is defined as the ratio between the measured content of the contaminant and the oral reference dose (RD), weighed by the length and frequency of exposure, amount ingested, and b.w.. The following equation was used (Equation (1)):

$$
\mathrm{THQ}=\{(\mathrm{EF} \times \mathrm{ED} \times \mathrm{FIR} \times \mathrm{C}) /(\mathrm{RfD} \times \mathrm{BW} \times \mathrm{AT})\} \times 10^{-3},
$$

where THQ is the target hazard quotient for noncarcinogenic risks, EF is the exposure frequency (365 days/year), ED is the exposure duration in years (approximately 70 years for adults and 10 years for children), FIR is the food ingestion rate (43 g/day for Sri Lanka and $54 \mathrm{~g}$ /day for Bangladesh), $\mathrm{C}$ is the average metal content of each group of fish species (mg/kg w.w.), RfD is the estimated oral reference dose of the metal (mg/kg/day, 0.003 for arsenic, 0.001 for cadmium, 0.0005 for mercury, and 0.004 for lead) [48], BW is the average 
b.w. of an adult $(60 \mathrm{~kg})$ and a child $(27 \mathrm{~kg})$, and $\mathrm{AT}$ is the average exposure time for noncarcinogen effect $(\mathrm{ED} \times 365$ days/year). A THQ $<1$ implies that there is no adverse hazard to human health, whereas a THQ value $>1$ implies potential health risks associated with fish intake and, therefore, related interventions and protective measures should be taken [48].

To assess the overall potential for noncarcinogenic effects from multiple metals, a hazard index (HI) was formulated, according to the guidelines for health risk assessment of chemical mixtures by the US EPA $[47,48]$. The HI is expressed as the sum of the THQ, and the equation is as follows (Equation (2)):

$$
\mathrm{HI}=\sum \mathrm{THQ} .
$$

\subsubsection{Carcinogenic Exposure}

For carcinogens, risk was estimated as the incremental probability of an individual to develop cancer over a lifetime exposure to potential carcinogens [47]. The target carcinogenic risk (TR) was calculated using the following equation (Equation (3)):

$$
\mathrm{TR}=\{(\mathrm{EF} \times \mathrm{ED} \times \mathrm{FIR} \times \mathrm{C} \times \mathrm{CSFo}) /(\mathrm{BW} \times \mathrm{AT})\} \times 10^{-3},
$$

where CSFo is the oral carcinogenic slope factor $(\mathrm{mg} / \mathrm{kg} \mathrm{b.w./} \mathrm{day)} \mathrm{from} \mathrm{the} \mathrm{Integrated} \mathrm{Risk}$ Information System database [49]: $1.5(\mathrm{mg} / \mathrm{kg} \mathrm{b.w.} / \text { day })^{-1}$ for arsenic, $0.38(\mathrm{mg} / \mathrm{kg} \text { b.w. } / \text { day })^{-1}$ for cadmium, and 0.0085 (mg/kg b.w./day) ${ }^{-1}$ for lead. As no CSFo value is known for mercury, TR was not calculated for this metal.

\section{Results}

\subsection{Sample Characteristics}

This study included a total of 1111 individual samples of fish comprising 24 different species from the pelagic, mesopelagic, demersal, and reef zones of the Bay of Bengal, sampled from Sri Lankan and Bangladeshi marine waters. An overview of the identification details and the weight and length parameters of all species sampled are described in Table 3. The Sri Lankan fish species Sphyraena jello had the greatest mean weight of $2885 \mathrm{~g}$ and mean length of $88.5 \mathrm{~cm}$.

\subsection{Metal Contents in Fish Species from Sri Lanka}

The arsenic, cadmium, mercury, and lead contents in the fish species from Sri Lanka, expressed on a wet weight basis, are listed in Table 4 . In general, the metal contents varied widely among different fish species; the mean content of arsenic in all fish samples was the highest $(1.9 \mathrm{mg} / \mathrm{kg})$, followed by cadmium $(0.19 \mathrm{mg} / \mathrm{kg})$, and mercury $(0.06 \mathrm{mg} / \mathrm{kg})$, whereas that of lead was the lowest $(0.01 \mathrm{mg} / \mathrm{kg})$. Additionally, the contents varied between small and large species, indicating that the size of the fish and/or which tissues of the fish are consumed may be of importance. The difference between small and large fish was significant for arsenic $(p=0.0059)$, cadmium $(p<0.0001)$, lead $(p<0.0001)$, and mercury $(p<0.001)$. The highest content of arsenic, $9.27 \mathrm{mg} / \mathrm{kg}$, was found in the small species Decapterus macrosoma ${ }^{1}$, followed by the large species Diagramma pictum, with $5.47 \mathrm{mg} / \mathrm{kg}$. However, the other sample of Decapterus macrosoma ${ }^{2}$, sampled at a different location, contained a substantially lower arsenic content $(0.83 \mathrm{mg} / \mathrm{kg})$. The mean arsenic content for small species was generally higher than that of large species. The highest content of cadmium, $1.043 \mathrm{mg} / \mathrm{kg}$, was also found in the same sample of Decapterus macrosoma ${ }^{1}$, which is more than 20 times above the maximum limit of $0.050 \mathrm{mg} / \mathrm{kg}$ set by the EU. Of the 12 small fish species analysed, 11 species (92\%) presented a cadmium content in excess of the maximum limit. The mean cadmium content in small species was also substantially higher than that of large species, where none exceeded the maximum limit set by the EU. This relationship was also found to be significant by a negative correlation coefficient $(r=-0.61, p<0.0001)$. For mercury, the highest content of $0.347 \mathrm{mg} / \mathrm{kg}$ was found in the large species Sphyraena jello. Contrary to the other metals, the mean mercury content was 
significantly higher in large species compared to small species, as evidenced by a positive correlation coefficient for length and mercury content $(r=0.81, p<0.0001)$. However, none of the sampled fish species from Sri Lanka exceeded the maximum value of $0.50 \mathrm{mg} / \mathrm{kg}$ for total mercury set by the EU. The highest content of lead, $0.081 \mathrm{mg} / \mathrm{kg}$, was found in the small species Leiognathus dussumieri; a value that is far from the maximum limit of $0.30 \mathrm{mg} / \mathrm{kg}$. Small species had a mean lead content approximately four times that of large species. Furthermore, a significant negative correlation between length and lead content was observed $(r=-0.76, p<0.0001)$.

Table 3. Identification details and physical parameters of fish species sampled from Sri Lanka and Bangladesh ${ }^{\mathrm{a}}$.

\begin{tabular}{|c|c|c|c|c|c|c|}
\hline \multirow{2}{*}{$\begin{array}{r}\text { Scientific Name } \\
\text { Fish from Sri Lanka }\end{array}$} & \multirow[t]{2}{*}{ Common Name } & \multicolumn{2}{|c|}{ Local Name } & \multirow[t]{2}{*}{ Habitat } & \multirow[t]{2}{*}{$\begin{array}{c}\text { Average Weight } \\
\text { (g) }{ }^{b}\end{array}$} & \multirow[t]{2}{*}{$\begin{array}{l}\text { Average Length } \\
\text { (cm) }\end{array}$} \\
\hline & & Sinhalese Name ${ }^{c}$ & Tamil Name $^{c}$ & & & \\
\hline \multicolumn{7}{|l|}{ Small fish } \\
\hline Amblygaster sirm & Trenched sardinella & Hurulla & Keerimeen saalai & Pelagic & $278 \pm 20$ & 10.5 \\
\hline Auxis thazard & Frigate tuna & Alagoduwa & Urulan soorai & Pelagic & $1180 \pm 27$ & 16.2 \\
\hline Decapterus macrosoma $^{1}$ & Shortfin scad & Linna & $\begin{array}{l}\text { Mundakan } \\
\text { kilichchi }\end{array}$ & Pelagic & $763 \pm 23$ & 13.5 \\
\hline Decapterus macrosoma ${ }^{2}$ & Shortfin scad & Linna & $\begin{array}{l}\text { Mundakan } \\
\text { kilichchi }\end{array}$ & Pelagic & $273 \pm 22$ & 9.2 \\
\hline Encrasicholina devisi & Devis' anchovy & Halmessa & Neththili & Pelagic & $219 \pm 1$ & 10.5 \\
\hline Equulites elongatus & Slender ponyfish & Karalla & Karal & Demersal & $183 \pm 8$ & 7.7 \\
\hline Leiognathus dussumieri & Dussumier's ponyfish & Karalla & Vari karai & Demersal & $637 \pm 56$ & 10.6 \\
\hline Photopectoralis bindus ${ }^{1}$ & Orangefin ponyfish & Karalla & Tatnam-kare & Demersal & $245 \pm 20$ & 7.4 \\
\hline Photopectoralis bindus ${ }^{2}$ & Orangefin ponyfish & Karalla & Tatnam-kare & Demersal & $228 \pm 10$ & 7.5 \\
\hline Rastrelliger kanagurta & Indian mackerel & Kumbalava & Kanang keluththi & Pelagic & $610 \pm 6$ & 12.5 \\
\hline Sillago ingenuиа & Bay whiting & $-d$ & Kelangan & Demersal & $1099 \pm 24$ & 16.3 \\
\hline Stolephorus indicus & Indian anchovy & Halmassa & Neththili & Pelagic & $676 \pm 10$ & 13.2 \\
\hline \multicolumn{7}{|l|}{ Large fish } \\
\hline Carangoides fulvoguttatus ${ }^{\mathrm{e}}$ & Yellowspotted trevally & Thumba parawa & Manjal parai & Reef-associated & $168 \pm 31$ & $20.5 \pm 1.5$ \\
\hline Diagramma pictum & Painted sweetlips & Gobaya & Kallu kallewa & Reef-associated & $1694 \pm 906$ & $47.9 \pm 7.5$ \\
\hline Lethrinus olivaceus & Long-face emperor & Uru hota & Thinan & Reef-associated & $1886 \pm 2275$ & $46.4 \pm 17.4$ \\
\hline Lutjanus lutjanus & Bigeye snapper & Hunu ranna & Nooleni & Demersal & $317 \pm 58$ & $27.5 \pm 1.8$ \\
\hline Nemipterus bipunctatus $\mathrm{e}$ & Delagoa threadfin bream & $-d$ & Cundil & Demersal & $78 \pm 45$ & $16.3 \pm 3.2$ \\
\hline Selar crumenophthalmus ${ }^{\mathrm{e}}$ & Bigeye scad & Bolla & Chooparai & Reef-associated & $174 \pm 45$ & $21.3 \pm 1.7$ \\
\hline Sphyraena jello & Pickhandle barracuda & Silava & Jeela & Reef-associated & $2885 \pm 557$ & $88.5 \pm 5.6$ \\
\hline \multicolumn{7}{|l|}{ Fish from Bangladesh } \\
\hline Benthosema fibulatum & Spinycheek lanternfish & \multicolumn{2}{|c|}{ Puiya } & Mesopelagic & 0.6 & $<5$ \\
\hline Bregmaceros mcclellandi & Unicorn cod & \multicolumn{2}{|c|}{$-\mathrm{d}$} & Mesopelagic & 0.5 & $<6$ \\
\hline Dussumieria elopsoides ${ }^{1}$ & Slender rainbow sardine & \multicolumn{2}{|c|}{ Maricha } & Pelagic & 49.7 & 17.0 \\
\hline Dussumieria elopsoides ${ }^{2}$ & Slender rainbow sardine & \multicolumn{2}{|c|}{ Maricha } & Pelagic & 72.6 & 20.3 \\
\hline Dussumieria elopsoides ${ }^{3}$ & Slender rainbow sardine & \multicolumn{2}{|c|}{ Maricha } & Pelagic & 67.8 & 19.3 \\
\hline Harpadon nehereus ${ }^{1}$ & Bombay duck & \multicolumn{2}{|c|}{ Loittya } & Demersal & 110.3 & 25.5 \\
\hline Harpadon nehereus ${ }^{2}$ & Bombay duck & \multicolumn{2}{|c|}{ Loittya } & Demersal & 117.7 & 24.2 \\
\hline Megalaspis cordyla & Torpedo scad & \multicolumn{2}{|c|}{ Kuawa } & Pelagic & 114.6 & 25.2 \\
\hline Pentaprion longimanus & Longfin mojarra & \multicolumn{2}{|c|}{ Dom Mach } & Demersal & 20.8 & 11.4 \\
\hline Sardinella fimbriata ${ }^{1}$ & Fringescale sardinella & \multicolumn{2}{|c|}{ Chapila } & Pelagic & 35.2 & 16.1 \\
\hline Sardinella fimbriata ${ }^{2}$ & Fringescale sardinella & \multicolumn{2}{|c|}{ Chapila } & Pelagic & 40.3 & 16.4 \\
\hline Sardinella fimbriata ${ }^{3}$ & Fringescale sardinella & \multicolumn{2}{|c|}{ Chapila } & Pelagic & 43.5 & 16.4 \\
\hline
\end{tabular}

${ }^{a}$ Values are presented as means \pm standard deviations (SD) and are based on length and weight values (prior to any handling) of the sampled fish species. ${ }^{\mathrm{b}}$ Weight measurements are expressed as the total weight of the composite sample consisting of $n$ number of fish for small species, and per individual fish for large species from Sri Lanka (see Table 2). The length of small fish species from Sri Lanka and all fish species from Bangladesh was calculated as a mean value of the first composite sample measured as a whole during the surveys; thus, no SD is presented. ${ }^{c}$ Only applicable for fish species from Sri Lanka. ${ }^{\mathrm{d}}$ The local names of all species were not available. ${ }^{\mathrm{e}}$ Species categorised as large fish (although their length was $<25 \mathrm{~cm}$ ) based on input on the eating practice of the species by the national scientists on board, for which only the fillet is commonly consumed (thus corresponding to the local eating practice of large fish and not small fish). $1,2,3$ Fish species sampled multiple times at separate locations. 
Table 4. Contents of arsenic (As), cadmium (Cd), mercury ( $\mathrm{Hg})$, and lead $(\mathrm{Pb})$ in fish species from Sri Lanka and Bangladesh (mean $\pm \mathrm{SD})$.

\begin{tabular}{|c|c|c|c|c|}
\hline Species $^{\text {a }}$ & $\begin{array}{c}\text { As } \\
(\mathrm{mg} / \mathrm{kg} \mathrm{w.w.)}\end{array}$ & $\begin{array}{c}\mathrm{Cd} \\
(\mathrm{mg} / \mathrm{kg} \mathrm{w.w.)}\end{array}$ & $\begin{array}{c}\mathrm{Hg} \\
(\mathrm{mg} / \mathrm{kg} \mathrm{w.w.)}\end{array}$ & $\begin{array}{c}\mathrm{Pb} \\
\text { (mg/kg w.w.) }\end{array}$ \\
\hline \multicolumn{5}{|l|}{ Fish from Sri Lanka } \\
\hline \multicolumn{5}{|l|}{ Small fish } \\
\hline Amblygaster sirm & $1.13 \pm 0.06$ & $0.300 \pm 0.026^{b}$ & $0.012 \pm 0.002$ & $0.011 \pm 0.001$ \\
\hline Auxis thazard & $1.10 \pm 0.00$ & $0.177 \pm 0.021^{c}$ & $0.005 \pm 0.001$ & $0.006 \pm 0.000$ \\
\hline Decapterus macrosoma ${ }^{1}$ & $9.27 \pm 1.02$ & $1.043 \pm 0.100^{b}$ & $0.031 \pm 0.005$ & $0.018 \pm 0.001$ \\
\hline Decapterus macrosoma $^{2}$ & $0.83 \pm 0.05$ & $0.467 \pm 0.035^{b}$ & $0.002 \pm 0.000$ & $0.006 \pm 0.001$ \\
\hline Encrasicholina devisi & $0.93 \pm 0.04$ & $0.303 \pm 0.023^{b}$ & $0.015 \pm 0.001$ & $0.009 \pm 0.001$ \\
\hline Equulites elongatus & $1.80 \pm 0.10$ & $0.103 \pm 0.006^{b}$ & $0.017 \pm 0.001$ & $0.012 \pm 0.002$ \\
\hline Leiognathus dussumieri & $3.77 \pm 0.38$ & $0.049 \pm 0.002$ & $0.034 \pm 0.003$ & $0.081 \pm 0.017$ \\
\hline Photopectoralis bindus 1 & $1.57 \pm 0.06$ & $0.072 \pm 0.040^{\mathrm{b}}$ & $0.007 \pm 0.001$ & $0.031 \pm 0.001$ \\
\hline Photopectoralis bindus ${ }^{2}$ & $1.90 \pm 0.17$ & $0.055 \pm 0.005^{b}$ & $0.007 \pm 0.007$ & $0.020 \pm 0.003$ \\
\hline Rastrelliger kanagurta & $0.69 \pm 0.03$ & $0.273 \pm 0.006^{b}$ & $0.003 \pm 0.001$ & $0.009 \pm 0.001$ \\
\hline Sillago ingenuиa & $1.33 \pm 0.12$ & $0.147 \pm 0.006^{b}$ & $0.019 \pm 0.004$ & $0.021 \pm 0.007$ \\
\hline Stolephorus indicus & $1.80 \pm 0.10$ & $0.507 \pm 0.020^{b}$ & $0.025 \pm 0.002$ & $0.008 \pm 0.001$ \\
\hline Mean for small fish & $2.18 \pm 2.32$ & $0.291 \pm 0.275$ & $0.015 \pm 0.011$ & $0.019 \pm 0.021$ \\
\hline \multicolumn{5}{|l|}{ Large fish } \\
\hline $\begin{array}{l}\text { Carangoides } \\
\text { fulvoguttatus }\end{array}$ & $1.50 \pm 0.30$ & $0.002 \pm 0.001$ & $0.035 \pm 0.004$ & $0.005 \pm 0.001$ \\
\hline Diagramma pictum & $5.47 \pm 0.06$ & $0.005 \pm 0.001$ & $0.094 \pm 0.016$ & $0.005 \pm 0.000$ \\
\hline Lethrinus olivaceus & $1.00 \pm 0.36$ & $0.001 \pm 0.000$ & $0.180 \pm 0.156$ & $0.005 \pm 0.000$ \\
\hline Lutjanus lutjanus & $0.69 \pm 0.15$ & $0.019 \pm 0.004$ & $0.150 \pm 0.026$ & $0.005 \pm 0.001$ \\
\hline Nemipterus bipunctatus & $0.58 \pm 0.09$ & $0.012 \pm 0.006$ & $0.048 \pm 0.015$ & $0.005 \pm 0.001$ \\
\hline Selar crumenophthalmus & $0.86 \pm 0.09$ & $0.027 \pm 0.018$ & $0.061 \pm 0.022$ & $0.006 \pm 0.000$ \\
\hline Sphyraena jello & $0.64 \pm 0.28$ & $0.005 \pm 0.002$ & $0.347 \pm 0.032$ & $0.005 \pm 0.000$ \\
\hline Mean for large fish & $1.53 \pm 1.69 *$ & $0.010 \pm 0.011^{* * *}$ & $0.131 \pm 0.116^{* *}$ & $0.005 \pm 0.001^{* * *}$ \\
\hline \multicolumn{5}{|l|}{ Fish from Bangladesh } \\
\hline Benthosema fibulatum & $2.33 \pm 0.06$ & $0.183 \pm 0.001^{b}$ & $0.010 \pm 0.001$ & $0.032 \pm 0.001$ \\
\hline Bregmaceros mcclellandi & $1.23 \pm 0.21$ & $0.033 \pm 0.002$ & $0.004 \pm 0.000$ & $0.025 \pm 0.015$ \\
\hline Dussumieria elopsoides 1 & $1.77 \pm 0.15$ & $0.133 \pm 0.032^{b}$ & $0.017 \pm 0.003$ & $0.007 \pm 0.002$ \\
\hline Dussumieria elopsoides ${ }^{2}$ & $1.04 \pm 0.14$ & $0.193 \pm 0.021^{b}$ & $0.020 \pm 0.000$ & $0.006 \pm 0.001$ \\
\hline Dussumieria elopsoides ${ }^{3}$ & $1.37 \pm 0.06$ & $0.163 \pm 0.006^{b}$ & $0.017 \pm 0.001$ & $0.006 \pm 0.000$ \\
\hline Harpadon nehereus ${ }^{1}$ & $0.09 \pm 0.01$ & $0.007 \pm 0.000$ & $0.005 \pm 0.000$ & $0.020 \pm 0.000$ \\
\hline Harpadon nehereus 2 & $0.18 \pm 0.04$ & $0.013 \pm 0.013$ & $0.005 \pm 0.001$ & $0.020 \pm 0.000$ \\
\hline Megalaspis cordyla & $2.23 \pm 0.23$ & $0.025 \pm 0.002$ & $0.058 \pm 0.009$ & $0.008 \pm 0.004$ \\
\hline Pentaprion longimanus & $3.13 \pm 0.35$ & $0.005 \pm 0.002$ & $0.016 \pm 0.001$ & $0.012 \pm 0.003$ \\
\hline Sardinella fimbriata ${ }^{1}$ & $3.07 \pm 0.06$ & $0.067 \pm 0.008^{b}$ & $0.017 \pm 0.001$ & $0.048 \pm 0.003$ \\
\hline Sardinella fimbriata ${ }^{2}$ & $2.87 \pm 0.06$ & $0.069 \pm 0.005^{b}$ & $0.017 \pm 0.000$ & $0.035 \pm 0.005$ \\
\hline Sardinella fimbriata ${ }^{3}$ & $2.23 \pm 0.06$ & $0.091 \pm 0.006^{b}$ & $0.015 \pm 0.002$ & $0.062 \pm 0.008$ \\
\hline Mean for all fish & $1.80 \pm 1.01$ & $0.082 \pm 0.069^{* * *}$ & $0.017 \pm 0.014^{* * *}$ & $0.023 \pm 0.018^{* * *}$ \\
\hline
\end{tabular}

${ }^{\text {a }}$ The analytical value for each fish species is the mean of three composite samples, consisting of $n$ number of samples (see Table 2)

${ }^{\mathrm{b}}$ Cadmium content exceeded the EU maximum limit of $0.050 \mathrm{mg} / \mathrm{kg}$ in muscle of fish. ${ }^{\mathrm{c}}$ Cadmium content exceeded the EU maximum limit of $0.15 \mathrm{mg} / \mathrm{kg}$ in muscle of Auxis spp. ${ }^{1,2,3}$ Fish species sampled multiple times at separate locations. ${ }^{*} p \leq 0.01$. Significant differences in metal contents when comparing the means of small and large fish species as a group for samples from Sri Lanka and the means of all fish species from Bangladesh to that of all fish species from Sri Lanka. ${ }^{* *} p \leq 0.001$. Significant differences in metal contents when comparing the means of small and large fish species as a group for samples from Sri Lanka and the means of all fish species from Bangladesh to that of all fish species from Sri Lanka. ${ }^{* * *} p \leq 0.0001$. Significant differences in metal contents when comparing the means of small and large fish species as a group for samples from Sri Lanka and the means of all fish species from Bangladesh to that of all fish species from Sri Lanka. Abbreviations: SD: standard deviation, w.w.: wet weight. 


\subsection{Metal Contents in Fish Species from Bangladesh}

The arsenic, cadmium, mercury, and lead contents in the sampled fish species from Bangladesh, expressed on a wet weight basis, are listed in Table 4. The mean metal contents in the fish species from Bangladesh followed a similar pattern to that of the fish species from Sri Lanka: highest for arsenic $(1.8 \mathrm{mg} / \mathrm{kg})$, followed by cadmium $(0.082 \mathrm{mg} / \mathrm{kg})$, mercury $(0.017 \mathrm{mg} / \mathrm{kg})$, and lead $(0.023 \mathrm{mg} / \mathrm{kg})$. The highest content of arsenic of $3.13 \mathrm{mg} / \mathrm{kg}$ was found in Pentaprion longimanus. For cadmium, seven of 12 species (58\%) exceeded the EU maximum limit of $0.050 \mathrm{mg} / \mathrm{kg}$, with the highest content $(0.193 \mathrm{mg} / \mathrm{kg})$ found in Dussumieria elopsoides ${ }^{2}$. However, the mean cadmium content in all fish species from Bangladesh was significantly lower than the mean of small species from Sri Lanka (0.082 and $0.291 \mathrm{mg} / \mathrm{kg}$, respectively, $p<0.0001)$. The highest mercury content, $0.058 \mathrm{mg} / \mathrm{kg}$, was found in Megalaspis cordyla; however, none of the samples exceeded the $\mathrm{EU}$ maximum value of $0.50 \mathrm{mg} / \mathrm{kg}$. Overall, the mean mercury content in the samples from Bangladesh was similar to that of small species from Sri Lanka $(0.017$ and $0.015 \mathrm{mg} / \mathrm{kg}$, respectively). For lead, the highest content, $0.062 \mathrm{mg} / \mathrm{kg}$, was found in one sample of Sardinella fimbriata; however, no samples exceeded the maximum limit of $0.30 \mathrm{mg} / \mathrm{kg}$. The mean lead content in the samples from Bangladesh was similar to that of small species from Sri Lanka (0.023 and $0.019 \mathrm{mg} / \mathrm{kg}$, respectively).

In terms of anatomical parts included in the analyses, the fish species from Bangladesh was most similar to that of large species from Sri Lanka (fillets with skin and intramuscular bones and fillets, respectively). When comparing the metal contents for these two groups (not including the two mesopelagic species from Bangladesh, as they were sampled whole), no significant differences were found for arsenic. However, the content of cadmium was significantly higher in the fish species from Bangladesh $(p=0.0001)$, whereas the content of mercury was significantly higher in the large species from Sri Lanka $(p<0.0001)$. For lead, the content was significantly higher in the fish species from Bangladesh $(p=0.0001)$.

\subsection{Potential Consumer Exposure}

Figure 1 shows how much one portion of the various fish species from Sri Lanka and Bangladesh contributes to the PTWI for MeHg as a percentage. The mean contribution from all small species from Sri Lanka was $1 \%$ for both adults and children, whereas large species contributed $6 \%$ and $8 \%$ for adults and children, respectively. The large species Sphyraena jello contributed most to the PTWI for both adults and children, with $16 \%$ and $21 \%$, respectively. Sphyraena jello is the only species that, if one portion was consumed every day for 1 week, would exceed the PTWI for $\mathrm{MeHg}$, with $112 \%$ for adults and 147\% for children. The species from Bangladesh contributed very little to the PTWI of MeHg, with a mean contribution of only $1 \%$ for all species for both adults and children. Megalaspis cordyla, sampled from Bangladesh, had the highest contribution to $\mathrm{MeHg}: 3 \%$ for adults and $4 \%$ for children. Figure 2 illustrates how much one portion per week for 1 month of the various fish species from Sri Lanka and Bangladesh contributes to the PTMI of cadmium as a percentage. Contrary to the PTWI of MeHg, the mean contribution to cadmium intakes from small species from Sri Lanka ( $3 \%$ and $4 \%$ for adults and children, respectively) was higher than that of large species ( $1 \%$ and $2 \%$ for adults and children, respectively). Despite relatively low mean values for all sampled fish species, the small species Decapterus macrosoma ${ }^{1}$ was identified to contribute substantially more than the other species, with $12 \%$ for adults and $16 \%$ for children. However, in order to exceed the PTMI for cadmium, a child would have to consume the species Decapterus macrosoma ${ }^{1}$ every day for an entire month (120\% of PTMI), whereas, for an adult, this consumption frequency would only account for $90 \%$ of the PTMI. Of the fish species from Bangladesh, Dussumieria epolsoides ${ }^{2}$ was identified as the species with the highest contribution to the PTMI of cadmium, with 3\% for adults and $4 \%$ for children. The mean contribution for all fish species from Bangladesh was $1 \%$ for adults and $2 \%$ for children. 


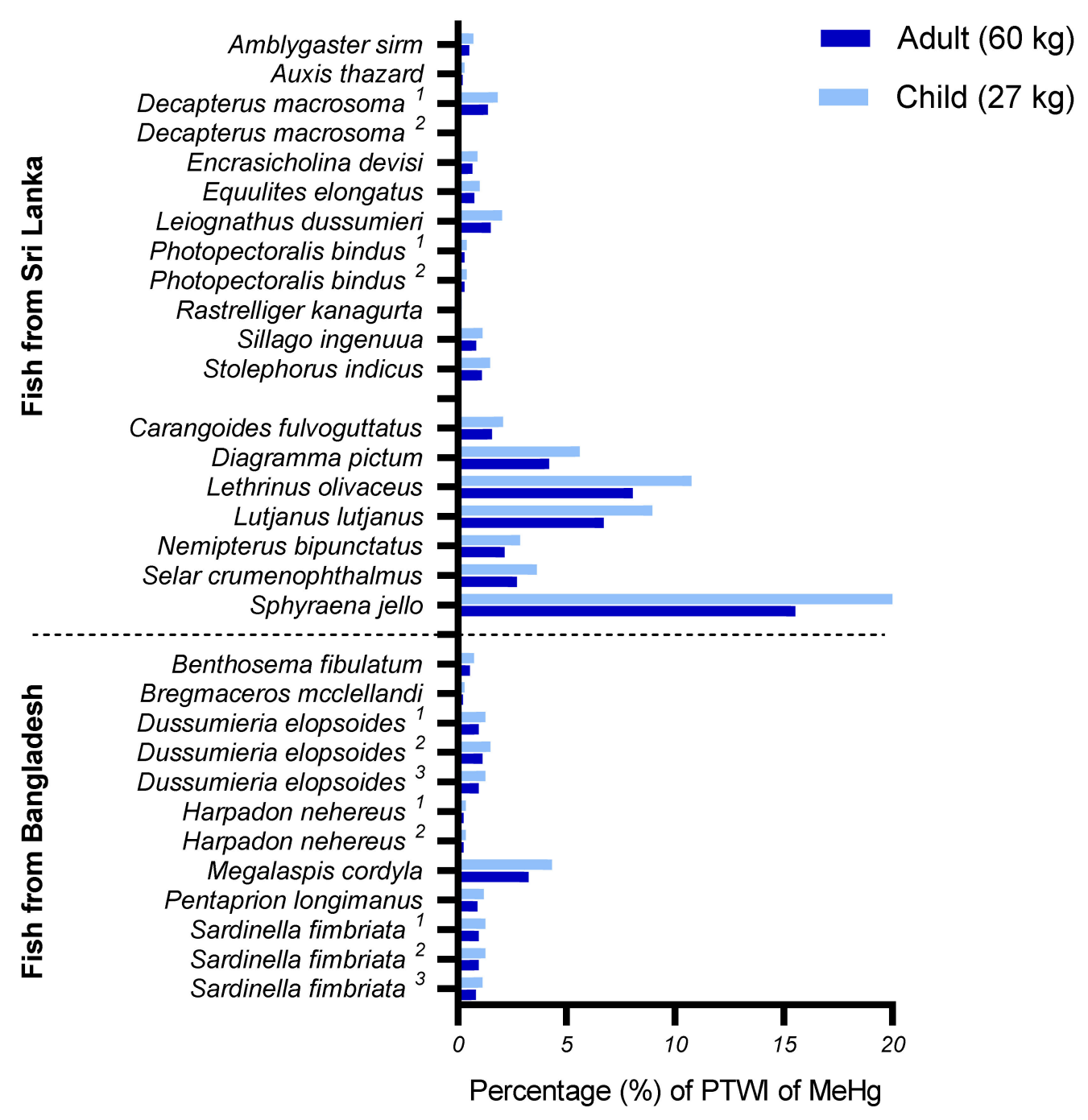

Figure 1. Potential consumer exposure for adults and children to methylmercury (MeHg), expressed as the metal content in one portion (43 and $26 \mathrm{~g}$ for Sri Lankan adults and children, respectively, and 54 and $32 \mathrm{~g}$ for Bangladeshi adults and children, respectively) of the various fish species from Sri Lanka and Bangladesh compared to the provisional weekly intake (PTWI) set by the JECFA. 1,2,3 Fish species sampled multiple times at separate locations.

\subsection{Health Risk Assessment in Edible Tissues of Different Fish Species}

The results of the health assessment of arsenic, cadmium, mercury, and lead regarding THQ, HI, and TR are presented in Table 5 for Sri Lanka and Bangladesh. THQ values for all metals were below the safe level of 1 for both adults and children, indicating that no adverse health effects are likely due to consumption of the sampled fish species with the present metal contents and consumption rates. When evaluating the effects from more than one metal, the HI was still below 1 for both adults and children, indicating no health risk. When evaluating the TR, the US EPA defines excess cancer risks as follows: a risk lower than approximately one chance in 1,000,000 $\left(1 \times 10^{-6}\right)$ is considered negligible, whereas chances above $1 \times 10^{-4}$ are sufficiently large to trigger some type of remediation [47]. Accordingly, cancer risks of less than $1 \times 10^{-4}$ are generally considered acceptable. The carcinogenic risk levels associated with cadmium and lead for both children and adults were less than $1 \times 10^{-4}$ for all species; this suggests that consuming these species is not associated with a high carcinogenic risk from exposure to cadmium or lead. However, the carcinogenic risk levels associated with arsenic for both adults and children exceeded the acceptable threshold level for all species, indicating potential cancer risks associated with consumption. 


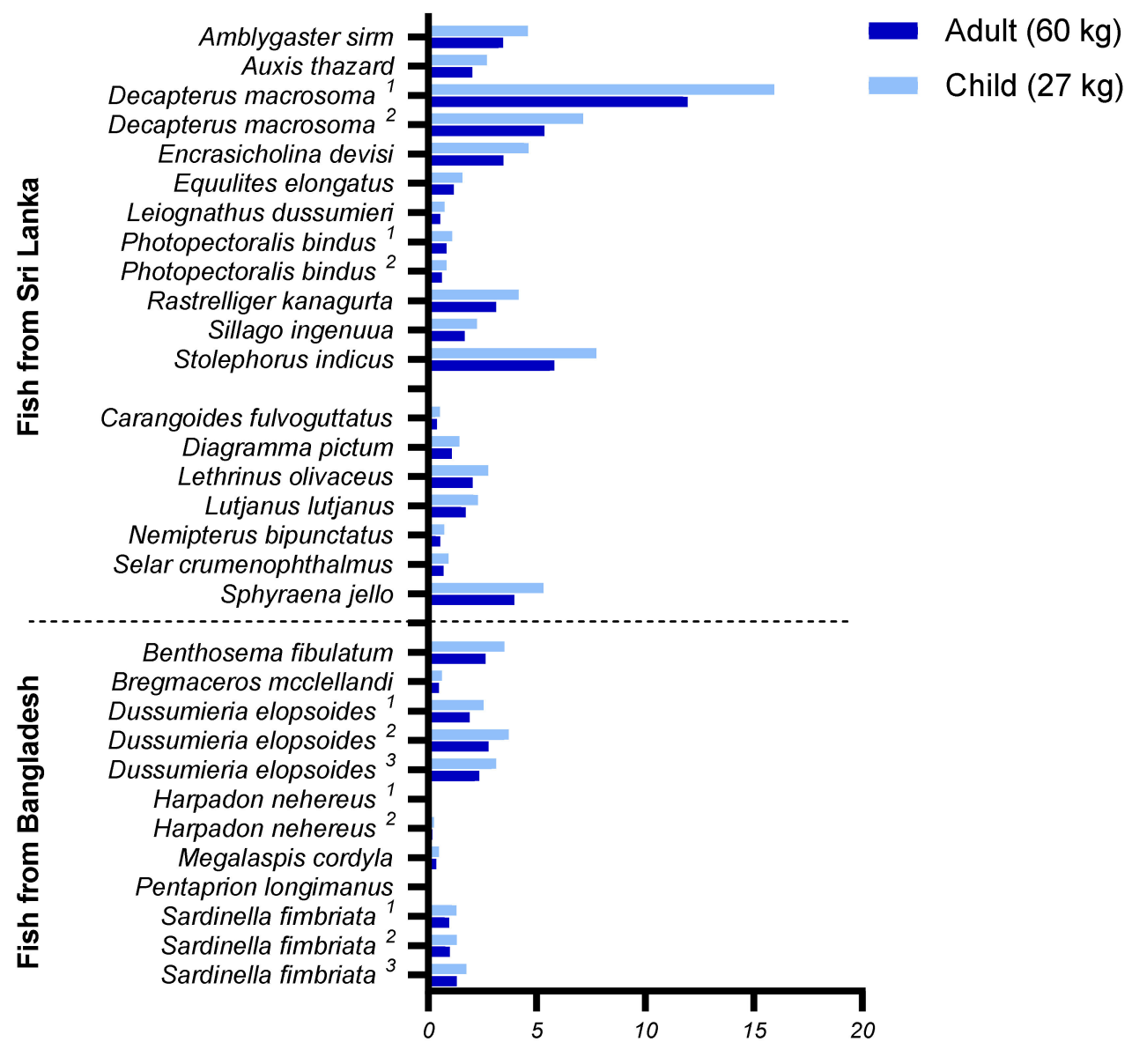

Percentage (\%) of PTMI of cadmium (Cd)

Figure 2. Potential consumer exposure for adults and children to cadmium (Cd), expressed as the metal content in one portion (43 and $26 \mathrm{~g}$ for Sri Lankan adults and children, respectively, and 54 and $32 \mathrm{~g}$ for Bangladesh adults and children, respectively) of the various fish species from Sri Lanka and Bangladesh compared to the provisional monthly intake (PTMI) set by the JECFA. For the calculations, a fish intake of four times per month (one time per week) for each fish species was assumed. 1,2,3 Fish species sampled multiple times at separate locations.

Table 5. Target hazard quotient (THQ), hazard index (HI), and target carcinogenic risk (TR) for arsenic, cadmium, mercury, and lead, based on estimated consumption rates of the fish species sampled from Sri Lanka and Bangladesh for adults $(60 \mathrm{~kg})$ and children $(27 \mathrm{~kg})$.

\begin{tabular}{|c|c|c|c|c|c|c|c|}
\hline \multirow[t]{3}{*}{ Metal } & \multirow{2}{*}{$\begin{array}{l}\text { Mean Metal Content (mg/kg w.w.) } \\
\text { Fish from Sri Lanka }\end{array}$} & \multicolumn{2}{|c|}{ THQ } & \multicolumn{2}{|c|}{ HI } & \multicolumn{2}{|c|}{ TR } \\
\hline & & & & & & & \\
\hline & Small Fish & Adults & Children & Adults & Children & Adults & Children \\
\hline As & 2.18 & 0.5208 & 0.6997 & \multirow{4}{*}{0.5984} & \multirow{4}{*}{0.8040} & $2.3 \times 10^{-3}$ & $3.1 \times 10^{-3}$ \\
\hline $\mathrm{Cd}$ & 0.291 & 0.0695 & 0.0934 & & & $7.9 \times 10^{-5}$ & $1.1 \times 10^{-4}$ \\
\hline $\mathrm{Hg}$ & 0.015 & 0.0036 & 0.0048 & & & $\mathrm{NA}^{\mathrm{a}}$ & $\mathrm{NA}^{\mathrm{a}}$ \\
\hline $\mathrm{Pb}$ & 0.019 & 0.0045 & 0.0060 & & & $1.2 \times 10^{-7}$ & $1.6 \times 10^{-7}$ \\
\hline \multicolumn{8}{|c|}{ Large fish } \\
\hline As & 1.530 & 0.3655 & 0.4911 & \multirow{4}{*}{0.4004} & \multirow{4}{*}{0.5379} & $1.6 \times 10^{-3}$ & $3.1 \times 10^{-3}$ \\
\hline $\mathrm{Cd}$ & 0.010 & 0.0024 & 0.0032 & & & $2.7 \times 10^{-6}$ & $3.7 \times 10^{-6}$ \\
\hline $\mathrm{Hg}$ & 0.131 & 0.0313 & 0.0420 & & & $\mathrm{NA}^{\mathrm{a}}$ & $\mathrm{NA}^{\mathrm{a}}$ \\
\hline $\mathrm{Pb}$ & 0.005 & 0.0012 & 0.0016 & & & $3.0 \times 10^{-8}$ & $4.1 \times 10^{-8}$ \\
\hline \multicolumn{8}{|c|}{ Fish from Bangladesh } \\
\hline As & 1.800 & 0.5400 & 0.7333 & \multirow[t]{4}{*}{0.5766} & \multirow[t]{4}{*}{0.7830} & $2.4 \times 10^{-3}$ & $3.3 \times 10^{-3}$ \\
\hline $\mathrm{Cd}$ & 0.082 & 0.0246 & 0.0334 & & & $2.8 \times 10^{-5}$ & $2.8 \times 10^{-5}$ \\
\hline $\mathrm{Hg}$ & 0.017 & 0.0051 & 0.0069 & & & $\mathrm{NA}^{\mathrm{a}}$ & $\mathrm{NA}^{\mathrm{a}}$ \\
\hline $\mathrm{Pb}$ & 0.023 & 0.0069 & 0.0093 & & & $1.8 \times 10^{-7}$ & $2.3 \times 10^{-7}$ \\
\hline
\end{tabular}

${ }^{a}$ Value not available due to no known carcinogenic slope factor (CSFo) for mercury. Abbreviations: As: arsenic, Cd: cadmium, HI: hazard index, Hg: mercury, Pb: lead, THQ: target hazard quotient, TR: target carcinogenic risk, w.w.: wet weight. 


\section{Discussion}

This paper presented analytical data on the contents of arsenic, cadmium, mercury, and lead in 24 different marine fish species from the Bay of Bengal, sampled from Bangladeshi and Sri Lankan marine waters. All but two of these fish species are readily available and commonly consumed in the respective countries. These two mesopelagic species were included due to limited knowledge on the chemical composition of such species and their potential contribution as food and/or feed. Contents of mercury and lead were far below the EU maximum limits in fish for all species, whereas all but one of the small species from Sri Lanka and more than half of the species from Bangladesh exceeded the EU maximum limits for cadmium. However, the PTWI/PTMI for mercury and cadmium were not exceeded for any fish species on the basis of estimated consumption rates for adults and children. For total arsenic in fish, no maximum limit or PTWI value has been established, and, for lead, no PTWI value has been established. To the best of our knowledge, this is the first study within the scientific literature to report the contents of arsenic, cadmium, mercury, and lead in several of the analysed fish species from Sri Lanka: the small species Encrasicholina devisi, Equulites elongatus, Leiognathus dussumieri, and Sillago ingenuua; the large species Lethrinus olivaceus and Nemipterus bipunctatus; and from Bangladesh, the two mesopelagic species Benthosema fibulatum and Bregmaceros mcclellandi, and Dussumieria elopsoides.

The speciation of the arsenic compounds present in fish is the most important toxicological endpoint for human health assessments, and the total arsenic content, which was measured in this study, is not considered suitable for risk estimations [50,51]. However, some countries have specified a maximum limit for total arsenic in seafood. For example, in Hong Kong, the maximum limit is $6 \mathrm{mg} / \mathrm{kg}$ for fish and fish products, whereas in Australia and New Zealand, the value is $2 \mathrm{mg} / \mathrm{kg}$ for fish and crustacea [52]. According to these values, several of the sampled fish species in this study would have exceeded the maximum limits. In our study, the highest content of arsenic was reported in the small species Decapterus macrosoma, with $9.27 \mathrm{mg} / \mathrm{kg}$. In a study where the arsenic content in fish fillet of cod, herring, mackerel, halibut, tusk, and saithe from the coast of Norway was analysed $(n=923)$, the authors reported that the content of total arsenic varied greatly between species, with values ranging from 0.3 to $110 \mathrm{mg} / \mathrm{kg}$ [53]. This is an extremely large range compared to the range of total arsenic reported in this study $(0.09-9.27 \mathrm{mg} / \mathrm{kg})$. In a Belgian market study, Ruttens et al. (2012) reported a mean range of $1.05-9.36 \mathrm{mg} / \mathrm{kg}$ in nine species of marine fish [54], which is much more similar to the results of this study. A similar range was also reported in a study from the coastal areas of Bangladesh; Raknuzzaman et al. (2016) reported contents ranging from $0.76-13 \mathrm{mg} / \mathrm{kg}$ in fresh fish. Furthermore, the authors also reported that the TR for adults was exceeded for arsenic with consumption of the sampled fish and crustacea from the Bay of Bengal [55]. In this study, the TR for both adults and children was also exceeded for arsenic in fish from Sri Lanka and Bangladesh. However, in this study, the content of total arsenic was analysed. The content of inorganic arsenic in fish, which is the toxic form, has in other studies been found to be very low, usually $<1 \%$ of the total arsenic content and often below quantifiable amounts $[51,53,54,56]$. Thus, analyses identifying the speciation of the arsenic compounds in the sampled fish species from Sri Lanka and Bangladesh are recommended to further evaluate the potential carcinogenic health risks associated with consumption. Nevertheless, as high consumers of rice, the Sri Lankan and Bangladeshi people may be at risk of exposure to inorganic arsenic at hazardous levels through rice consumption, as inorganic arsenic accounts for a large proportion of the total arsenic in rice. Additionally, elevated contents of inorganic arsenic in the groundwater (and, consequently, drinking water) present a major problem in both countries, particularly in Bangladesh [52,57].

The mean cadmium content in small fish from Sri Lanka significantly exceeded that of both large fish from Sri Lanka and all fish from Bangladesh (0.291, 0.010, and 0.082, respectively). In a scientific report by the European Food Safety Authority (EFSA) assessing the cadmium content in fish from 20 member states of the EU $(n=6393)$, the mean content 
reported was $0.0137 \mathrm{mg} / \mathrm{kg}$, which is in line with the mean values presented in this study for large fish from Sri Lanka and fish from Bangladesh. However, this value is considerably lower than the cadmium content in the small fish species from Sri Lanka. The maximum value reported in the report was $0.3000 \mathrm{mg} / \mathrm{kg}$, a value that is closer to that of small species from Sri Lanka $(0.291 \mathrm{mg} / \mathrm{kg})$ [58]. In general, the cadmium content in the large fish species from Sri Lanka was similar to that of other large fish species sampled in the same area of the Bay of Bengal: yellowfin tuna $(0.01 \mathrm{mg} / \mathrm{kg})$, swordfish $(0.09 \mathrm{mg} / \mathrm{kg})$, black marlin $(0.02 \mathrm{mg} / \mathrm{kg})$, and red snapper $(0.01 \mathrm{mg} / \mathrm{kg})$ [59]. Of the small species sampled from Sri Lanka, considerably lower cadmium contents been reported in the literature (predominantly from other Asian countries): $0.06 \mathrm{mg} / \mathrm{kg}$ [60] and $0.03 \mathrm{mg} / \mathrm{kg}$ [61] for Auxis Thazard $(0.18 \mathrm{mg} / \mathrm{kg}$ in this study), $0.04 \mathrm{mg} / \mathrm{kg}$ [60] and $0.008 \mathrm{mg} / \mathrm{kg}$ [61] for Decapterus macrosoma (mean value of $0.76 \mathrm{mg} / \mathrm{kg}$ in this study), $0.27 \mathrm{mg} / \mathrm{kg}$ [61] for Stolephorus indicus $(0.51 \mathrm{mg} / \mathrm{kg}$ in this study), and $0.03 \mathrm{mg} / \mathrm{kg}$ for Rastrelliger kanagurta $(0.27 \mathrm{mg} / \mathrm{kg}$ in this study) [62]. However, cadmium accumulation in fish is not homogeneous. Cadmium accumulates primarily in the kidneys, followed by the liver and gills of fish $[63,64]$. This may account for the significant differences observed between large and small fish species from Sri Lanka, as the head and viscera were excluded from the analyses of large fish and in most of the fish species from Bangladesh. Nevertheless, the two mesopelagic species from Bangladesh were both sampled whole and presented great differences in cadmium content; Benthosema fibulatum contained a more than five times higher content of cadmium than Bregmaceros mcclellandi, which had quite low contents of cadmium compared to the other species.

Over the last 10 years, the European Union's Rapid Alert System for Food and Feed (RASFF) reported four and 69 notifications for Bangladeshi and Sri Lankan exports of fish and fish products, respectively. Of the four cases from Bangladesh, none were related to metal contamination, whereas, of the 27 cases related to metal contamination in Sri Lanka, 26 were related to mercury contents that exceeded the EU maximum limit of $0.50 \mathrm{mg} / \mathrm{kg}$. The 26 cases were all for large fish species such as swordfish, tuna, and barracuda [65]. Generally, higher contents are observed in older and larger fish across and within species, as the mercury content is related to the age of the fish (as the fish have had longer time to accumulate mercury) and the position of the fish species within the food chain (bioaccumulation and biomagnification) [26]. The one species of barracuda (Sphyraena jello) included in this study contained a considerably higher content of mercury compared to all the other fish species $(0.348 \mathrm{mg} / \mathrm{kg})$ and was also substantially larger than the other species $(88.5 \mathrm{~cm})$. In a review article on mercury content in fish from Sri Lanka, Jinadasa et al. (2019) reported that most fish species were below the maximum limit, except for certain top-trophic-level fish species (swordfish, tuna, and marlin) [13]. In this study, Sphyraena jello was the only species to exceed the PTWI for MeHg if consumed every day by adults and children for a week. However, this is a worst-case scenario, and it is unlikely that an individual's entire weekly fish intake consists of a single species with the highest content of mercury. In both Sri Lanka and Bangladesh, the consumption of small fish is more frequent in the diets of the poor, whereas households of higher socioeconomic status purchase larger fish species and often consume only the fillets [66,67]. Therefore, according to the results of this study, the poor, as high consumers of small fish species, may be at a lower risk of exposure to high contents of $\mathrm{MeHg}$.

None of the analysed species in this study presented values close to the maximum limit of lead; $42 \%$ of the samples were below the LOQ, indicating that most species, especially large species from Sri Lanka, are not significant sources of lead exposure. Lead is mostly accumulated in the gills, liver, kidneys, and bones of fish [68]. This may explain the significant difference between large and small fish species sampled from Sri Lanka in this study, as these anatomical parts were excluded in the samples of large fish, thus possibly resulting in a lower lead content.

The metal bioaccumulation in fish is influenced by biotic and abiotic factors, such as the habitat and trophic level, geographic region, the temperature, salinity, and $\mathrm{pH}$ 
value of the surrounding water, as well as the age, gender, body mass, and diet of the fish [64]. This may explain the large differences in both arsenic and cadmium content between the two samples of Decapterus macrosoma from Sri Lanka (9.27 and $0.83 \mathrm{mg}$ arsenic per $\mathrm{kg}$ and 1.04 and $0.47 \mathrm{mg}$ cadmium per $\mathrm{kg}$, respectively). This difference was not seen in any of the other samples from Bangladesh that were also sampled multiple times from different locations. In this paper, we reported significant differences between the length of the sampled fish species and their metal content. A possible explanation for the negative relationship between length and metal content for arsenic, cadmium, and lead is the difference in metabolic activity between younger and older fish, where age often corresponds to the size of the fish. The metabolic activity of younger individuals is higher than that of older individuals, and metal accumulation increases with higher metabolic activity; thus, younger individuals often have higher contents [69]. However, this dilution of tissue metal content due to growth and lowered metabolic activity is not seen for mercury, where a positive relationship exists between length and metal content due to biomagnification [26].

In this paper, we estimated the potential consumer exposure for adults and children on the basis of the average fish intake in Sri Lanka and Bangladesh as calculated from the respective HIES, due to the lack of comprehensive national dietary data and nutrition studies. However, a number of reliability issues are related to the use of such data (e.g., the lack of information on intra-household food distribution and the reliability of surveys employing interview methods in general) [70]. In addition, assumptions that the intake is higher for some individuals of the population must be assumed but were not accounted for in this paper. According to our data, the Sri Lankan and Bangladeshi populations are likely at minimal risk of metal exposure at a hazardous level from consumption of the fish species included in this paper. However, other seafoods, such as crustaceans, molluscs, and cephalopods, are also major sources of metals and an important part of the Sri Lankan and Bangladeshi diet $[51,58,68,71]$. Due to the omission of other seafoods when assessing the potential consumer exposure, we cannot exclude that the potential consumer exposure might be at a higher level than that assessed in this study. However, fish and seafood provide millions of people around the world with a vast variety of essential nutrients and represent a cheap and easily available means of nutritional diversification for people in many low- and middle-income countries, such as Sri Lanka and Bangladesh, that depend heavily on a narrow range of staple foods [5]. When evaluating the benefits and risks of fish and seafood consumption, EFSA concluded that the benefits (reduced cardiovascular disease in adults and improved functional neurodevelopment in children with fish consumption during pregnancy) of fish and seafood consumption in the range of 1-4 servings per week generally outweigh the potential risks (with some exceptions for species with high contents of mercury) [26]. This was also the conclusion in the Expert Opinion by the FAO/WHO in 2010 [72]. Although food safety issues are a continuous concern, reaching the Sustainable Development Goals (SDGs) by 2030 will not be feasible if fish and seafood are not part of key strategies, as fish and seafood play a key role in human nutrition and health, as well as the economic, social, and environmental sustainability of food systems [5].

\section{Conclusions}

In this paper, we presented analytical data on the contents of arsenic, cadmium, lead, and mercury in a large variety of marine fish species from the Bay of Bengal, several of which have not been analysed before. Our findings showed that the contents of mercury and lead in all of the sampled fish species did not exceed the EU maximum limits, and that the exposure to these metals from estimated daily fish consumption of the analysed fish species are minimal for adults and children. However, in several fish species, particularly the small species, the EU maximum limit for cadmium was exceeded. Nevertheless, the potential consumer exposure for cadmium was considered insignificant for both adults and children, given the estimated mean fish consumption rates in Sri Lanka and Bangladesh. 
Significant differences between small and large fish from Sri Lanka were found for all metals; small species had significantly higher contents of arsenic, cadmium, and lead, whereas large species presented a significantly higher content of mercury. The data presented in this study suggest that the sampled fish species pose no health risks to adults and children when consumed at estimated consumption rates and represent an important contribution to future risk/benefit assessments.

Author Contributions: Conceptualisation, M.K., S.H.T. and I.A.; validation, M.K. and A.-K.L.; formal analysis, A.M.R. and Z.R.; investigation, A.M.R. and A.N.; writing-original draft preparation, A.M.R.; writing—review and editing, A.M.R., Z.R., M.K., E.G.G., S.H.T., L.M.P., J.R., I.A., S.A., A.N. and A.-K.L.; visualization, A.M.R.; supervision, M.K.; project administration, M.K.; funding acquisition, M.K. All authors read and agreed to the published version of the manuscript.

Funding: This research was funded by the Norwegian Agency for Development Cooperation (Norad).

Institutional Review Board Statement: Not applicable.

Informed Consent Statement: Not applicable.

Data Availability Statement: All data generated or analysed during this study are included in this published article.

Acknowledgments: The authors are grateful to Anne-Karin Syversen, Leikny Fjellstad, and Edel Erdal for their positive and enthusiastic engagement in organising the project samples stored and analysed at the IMR. We would also like to express our gratitude to all the cruise participants on Fridtjof Nansen and the laboratory technicians at IMR that have contributed to establishing and performing the analytical methods and to producing high-quality analytical data. Lastly, we would like to acknowledge Gabriella Bianchi, Kathrine Michalsen, and Merete Tandstad for their help and guidance in the EAF-Nansen project.

Conflicts of Interest: The authors declare no conflict of interest. The funders had no role in the design of the study; in the collection, analyses, or interpretation of data; in the writing of the manuscript, or in the decision to publish the results.

\section{References}

1. Hicks, C.C.; Cohen, P.J.; Graham, N.A.J.; Nash, K.L.; Allison, E.H.; D’Lima, C.; Mills, D.J.; Roscher, M.; Thilsted, S.H.; ThorneLyman, A.L.; et al. Harnessing global fisheries to tackle micronutrient deficiencies. Nature 2019, 574, 95-98. [CrossRef]

2. Khalili Tilami, S.; Sampels, S. Nutritional Value of Fish: Lipids, Proteins, Vitamins, and Minerals. Rev. Fish. Sci. Aquac. 2018, 26, 243-253. [CrossRef]

3. Reksten, A.M.; Somasundaram, T.; Kjellevold, M.; Nordhagen, A.; Bøkevoll, A.; Pincus, L.M.; Rizwan, A.A.M.; Manun, A.; Thilsted, S.H.; Htut, T.; et al. Nutrient composition of 19 fish species from Sri Lanka and potential contribution to food and nutrition security. J. Food Compost. Anal. 2020, 91, 103508. [CrossRef]

4. Nordhagen, A.; Rizwan, A.A.M.; Aakre, I.; Moxness Reksten, A.; Pincus, L.M.; Bøkevoll, A. Nutrient Composition of Demersal, Pelagic, and Mesopelagic Fish Species Sampled Off the Coast of Bangladesh and Their Potential Contribution to Food and Nutrition Security-The EAF-Nansen Programme. Foods 2020, 9, 730. [CrossRef] [PubMed]

5. FAO. The State of World Fisheries and Aquaculture; FAO: Rome, Italy, 2018. Available online: http://www.fao.org/documents/ card/en/c/I9540EN/ (accessed on 23 October 2018).

6. Fiedler, J.L.; Lividini, K.; Drummond, E.; Thilsted, S.H. Strengthening the contribution of aquaculture to food and nutrition security: The potential of a vitamin A-rich, small fish in Bangladesh. Aquaculture 2016, 452, 291-303. [CrossRef]

7. Ministry of Fisheries and Aquatic Resources Development. Annual Performance Report Colombo, Sri Lanka. 2016. Available online: https:/ / www.parliament.lk/uploads/documents/paperspresented/performance-report-ministry-of-fisheries-aquatic2016.pdf (accessed on 25 January 2020).

8. He, Z.L.; Yang, X.E.; Stoffella, P.J. Trace elements in agroecosystems and impacts on the environment. J. Trace Elem. Med. Biol. Organ Soc. Miner. Trace Elem. GMS 2005, 19, 125-140. [CrossRef] [PubMed]

9. Bradl, H.B. (Ed.) Heavy Metals in the Environment: Origin, Interaction and Remediation; Academic Press: London, England, 2005; Volume 6.

10. Jarup, L. Hazards of heavy metal contamination. Br. Med. Bull. 2003, 68, 167-182. [CrossRef] [PubMed]

11. Ali, H.; Khan, E.; Ilahi, I. Environmental Chemistry and Ecotoxicology of Hazardous Heavy Metals: Environmental Persistence, Toxicity, and Bioaccumulation. J. Chem. 2019, 2019, 1-14. [CrossRef]

12. Ahmad, M.K.; Islam, S.; Rahman, M.; Haque, M.; Islam, M. Heavy Metals in Water, Sediment and Some Fishes of Buriganga River, Bangladesh. Int. J. Environ. Res. 2010, 4, 321-332. 
13. Jinadasa, B.; Fowler, S.W. Critical review of mercury contamination in Sri Lankan fish and aquatic products. Mar. Pollut. Bull. 2019, 149, 110526. [CrossRef]

14. Ahmed, A.S.S.; Rahman, M.; Sultana, S.; Babu, S.M.O.F.; Sarker, M.S.I. Bioaccumulation and heavy metal concentration in tissues of some commercial fishes from the Meghna River Estuary in Bangladesh and human health implications. Mar. Pollut. Bull. 2019, 145, 436-447. [CrossRef] [PubMed]

15. Tchounwou, P.B.; Yedjou, C.G.; Patlolla, A.K.; Sutton, D.J. Heavy metal toxicity and the environment. Exp. Suppl. 2012, 101, 133-164.

16. Singh, R.; Gautam, N.; Mishra, A.; Gupta, R. Heavy metals and living systems: An overview. Indian J. Pharmacol. 2011, 43, 246-253. [CrossRef] [PubMed]

17. United Nations Conference on Trade and Development (UNCTAD). Fishery Exports and the Economic Development of Least Developed Countries: Bangladesh, Cambodia, The Comoros, Mozambique, Myanmar and Uganda; United Nations: New York, NY, USA; Geneva, Switzerland, 2017.

18. Saha, N.; Mollah, M.Z.I.; Alam, M.F.; Safiur Rahman, M. Seasonal investigation of heavy metals in marine fishes captured from the Bay of Bengal and the implications for human health risk assessment. Food Control. 2016, 70, 110-118. [CrossRef]

19. Ahmed, F.E. (Ed.) Institute of Medicine (US) Committee on Evaluation of the Safety of Fishery Products: Chapter 5; National Academies Press (US): Washington, DC, USA, 1991.

20. Castro-Gonzalez, M.I.; Mendez-Armenta, M. Heavy metals: Implications associated to fish consumption. Environ. Toxicol. Pharmacol. 2008, 26, 263-271. [CrossRef]

21. Francesconi, K.A. Arsenic species in seafood: Origin and human health implications. Pure Appl. Chem. 2010, 82, 373-381. [CrossRef]

22. Johnston, J.E.; Hoffman, K.; Wing, S.; Lowman, A. Fish Consumption Patterns and Mercury Advisory Knowledge among Fishers in the Haw River Basin. N. C. Med. J. 2016, 77, 9-14. [CrossRef]

23. European Commission. Commission Regulation (EC), No 1881/2006 of setting maximum levels for certain contaminants in foodstuffs. Off. J. Eur. Comm. L 2006, 364, 5-24.

24. Codex Alimentarius Commission. General Standard for Contaminants and Toxins in Food and Feed (Codex Stan 193-1995); FAO: Rome, Italy; WHO: Geneve, Switzerland, 2017.

25. Commission Regulation (EU). No 488/2014 of 12 May 2014 amending Regulation (EC) No 1881/2006 as regard maximum levels of cadmium in foodstuffs, Text with EEA relevance. Off. J. Eur. Comm. L 2014, 138, 75-79.

26. European Food Safety Authority (EFSA). Scientific Opinion on the risk for public health related to the presence of mercury and methylmercury in food. EFSA J. 2012, 10, 2985.

27. Herrman, J.L.; Younes, M. Background to the ADI/TDI/PTWI. Regul. Toxicol. Pharmacol. 1999, 30, 109-113. [CrossRef] [PubMed]

28. Joint FAO/WHO Expert Committee on Food Additives (JECFA). Proceedings of the 73rd Joint FAO/WHO Expert Committee on Food Additives (JECFA) Meeting-Food Additives and Contaminants, Geneva, Switzerland, 8-17 June 2010.

29. Joint FAO/WHO Expert Committee on Food Additives (JECFA). Proceedings of the Evaluation of Certain Food Additives and Contaminants: Sixty-Seventh Report of the Joint FAO/WHO Expert Committee on Food Additives, Rome, Italy, 20-29 June 2006.

30. World Health Organization (WHO); Food and Agriculture Organization of the United Nations (FAO); Joint FAO/WHO Expert Committee on Food Additives. Evaluation of Certain Contaminants in Food: Seventy-Second [72nd] Report of the Joint FAO/WHO Expert Committee on Food Additives; World Health Organization: Geneva, Switzerland, 2011.

31. Hasan, M.R.; Khan, M.Z.H.; Khan, M.; Aktar, S.; Rahman, M.; Hossain, F.; Hasan, A.S.M.M. Heavy metals distribution and contamination in surface water of the Bay of Bengal coast. Cogent. Environ. Sci. 2016, 2, 1140001. [CrossRef]

32. Ahmed, A.S.S.; Sultana, S.; Habib, A.; Ullah, H.; Musa, N.; Hossain, M.B.; Rahman, M.M.; Sarker, M.S.I. Bioaccumulation of heavy metals in some commercially important fishes from a tropical river estuary suggests higher potential health risk in children than adults. PLoS ONE 2019, 14, e0219336. [CrossRef]

33. Naigaga, I.; Kaiser, H.; Muller, W.; Ojok, L.; Dismas, M.; Magezi, G.; Muhumuza, E. Fish as bioindicators in aquatic environmental pollution assessment: A case study in Lake Victoria wetlands, Uganda. Phys. Chem. Earth 2011, 36, 918-928. [CrossRef]

34. Abdel-Mohsein, H.; Mahmoud, M. Accumulation of Some Heavy Metals in Oreochromis niloticus from the Nile in Egypt: Potential Hazards to Fish and Consumers. J. Environ. Prot. 2015, 6, 1003-1013. [CrossRef]

35. Moxness Reksten, A.; Bøkevoll, A.; Frantzen, S.; Lundebye, A.-K.; Kögel, T.; Kolås, K.; Aakre, I.; Kjellevold, M. Sampling protocol for the determination of nutrients and contaminants in fish and other seafood-The EAF-Nansen Programme. MethodsX 2020, 7 , 101063. [CrossRef] [PubMed]

36. Zaza, S.; de Balogh, K.; Palmery, M.; Pastorelli, A.A.; Stacchini, P. Human exposure in Italy to lead, cadmium and mercury through fish and seafood product consumption from Eastern Central Atlantic Fishing Area. J. Food Compos. Anal. 2015, 40, 148-153. [CrossRef]

37. Dellatte, E.; Brambilla, G.; Miniero, R.; Abete, M.C.; Orletti, R.; Chessa, G.; Ubaldi, A.; Chiaravalle, E.; Tiso, M.; Ferrari, A. Individual methylmercury intake estimates from local seafood of the Mediterranean Sea, in Italy. Regul. Toxicol. Pharmacol. 2014, 69, 105-112. [CrossRef]

38. Carbonell, G.; Bravo, J.C.; Fernández, C.; Tarazona, J.V. A New Method for Total Mercury and Methyl Mercury Analysis in Muscle of Seawater Fish. Bull. Environ. Contam. Toxicol. 2009, 83, 210-213. [CrossRef] 
39. Traina, A.; Bono, G.; Bonsignore, M.; Falco, F.; Giuga, M.; Quinci, E.M. Heavy metals concentrations in some commercially key species from Sicilian coasts (Mediterranean Sea): Potential human health risk estimation. Ecotoxicol. Environ. Saf. 2019, 168, 466-478. [CrossRef] [PubMed]

40. Bonsignore, M.; Salvagio Manta, D.; Oliveri, E.; Sprovieri, M.; Basilone, G.; Bonanno, A. Mercury in fishes from Augusta Bay (southern Italy): Risk assessment and health implication. Food Chem. Toxicol. 2013, 56, 184-194. [CrossRef]

41. Wickramanayake, T.W. The Growth Chart. Sri Lanka J. Child Health 2009, 29, 18-22. [CrossRef]

42. Bangladesh Institute of Research and Rehabilitation in Diabetes; Endocrine and Metabolic Disorders (BIRDEM). Dietary Guidelines for Bangladesh. Dhaka: Bangladesh Institute of Research and Rehabilitation in Diabetes; Endocrine and Metabolic Disorders: Dhaka, Bangladesh, 2013.

43. Walpole, S.C.; Prieto-Merino, D.; Edwards, P.; Cleland, J.; Stevens, G.; Roberts, I. The weight of nations: An estimation of adult human biomass. BMC Public Health 2012, 12, 439. [CrossRef] [PubMed]

44. Department of Census and Statistics, Ministry of National Policies and Economic Affairs Sri Lanka. Household Income and Expenditure Survey 2016; Department of Census and Statistics: Colombo, Sri Lanka, 2016. Available online: http:/ / www.statistics gov.lk/HIES/HIES2016/HIES2016_FinalReport.pdf (accessed on 11 January 2019).

45. The Ministry of Fisheries and Aquaculture Resources. Fisheries Statistics; Ministry of Fisheries and Aquatic Resources: Colombo, Sri Lanka, 2016.

46. Bogard, J.R.; Farook, S.; Marks, G.C.; Waid, J.; Belton, B.; Ali, M.; Thilsted, S.H. Higher fish but lower micronutrient intakes: Temporal changes in fish consumption from capture fisheries and aquaculture in Bangladesh. PLoS ONE 2017, 12, e0175098.

47. United States Envonmental Protection Agency (USEPA). Risk Assessment: Guidance for Superfund; Human Health Evaluation Manual (Part A), Interim Final (EPA/540/1-89/002); United States Environmental Protection Agency: Washington, DC, USA, 1989; Volume 1.

48. Varol, M.; Kaya, G.K.; Alp, A. Heavy metal and arsenic concentrations in rainbow trout (Oncorhynchus mykiss) farmed in a dam reservoir on the Firat (Euphrates) River: Risk-based consumption advisories. Sci. Total Environ. 2017, 599-600, 1288-1296. [CrossRef] [PubMed]

49. United States Envonmental Protection Agency (USEPA). Regional Screening Level (RSL) Summary Table (TR=1E-06, HQ=1), Edition of the Drinking Water Standards and Health Advisories; Office of Water, United States Environmental Protection Agency: Washington, DC, USA, 2019. Available online: http://www.epa.gov/regshwmd/risk/human/Index.htm (accessed on 10 February 2002).

50. Chiocchetti, G.; Jadán-Piedra, C.; Vélez, D.; Devesa, V. Metal(loid) contamination in seafood products. Crit. Rev. Food Sci. Nutr. 2017, 57, 3715-3728. [CrossRef]

51. European Food Safety Authority (EFSA). Scientific Opinion on Arsenic in Food. EFSA J. 2009, 7, 1351. [CrossRef]

52. Jinadasa, K.; Fowler, S. A Critical Review of Arsenic Contamination in Sri Lankan Foods. J. Food Qual. Hazards Control. 2019, 6, 134-145. [CrossRef]

53. Julshamn, K.; Nilsen, B.; Frantzen, S.; Valdersnes, S.; Maage, A.; Nedreaas, K.; Sloth, J.J. Total and inorganic arsenic in fish samples from Norwegian waters. Food Addit. Contam. Part B Surveill. 2012, 5, 229-235. [CrossRef] [PubMed]

54. Ruttens, A.; Blanpain, A.C.; De Temmerman, L.; Waegeneers, N. Arsenic speciation in food in Belgium: Part 1: Fish, molluscs and crustaceans. J. Geochem. Explor. 2012, 121, 55-61. [CrossRef]

55. Raknuzzaman, M.; Islam, M.; Al Mamun, M.H.; Tokumura, M.; Sekine, M.; Masunaga, S. Trace metal contamination in commercial fish and crustaceans collected from coastal area of Bangladesh and health risk assessment. Environ. Sci. Pollut. Res. 2016, 23, 17298-17310. [CrossRef]

56. Mania, M.; Rebeniak, M.; Szynal, T.; Wojciechowska-Mazurek, M.; Starska, K.; Ledzion, E.; Postupolski, J. Total and inorganic arsenic in fish, seafood and seaweeds-Exposure assessment. Rocz. Panstw. Zakl. Hig. 2015, 66, 203-210. [PubMed]

57. Das, H.K.; Mitra, A.K.; Sengupta, P.K.; Hossain, A.; Islam, F.; Rabbani, G.H. Arsenic concentrations in rice, vegetables, and fish in Bangladesh: A preliminary study. Environ. Int. 2004, 30, 383-387. [CrossRef] [PubMed]

58. European Food Safety Authority (EFSA). Cadmium in food-Scientific opinion of the Panel on Contaminants in the Food Chain. EFSA J. 2009, 7, 980.

59. Jinadasa, B.K.; Edirisinghe, E.M.; Wickramasinghe, I. Total mercury, cadmium and lead levels in main export fish of Sri Lanka. Food Addit. Contam. Part B Surveill. 2014, 7, 309-314. [CrossRef]

60. Gu, Y.-G.; Ning, J.-J.; Ke, C.-L.; Huang, H.-H. Bioaccessibility and human health implications of heavy metals in different trophic level marine organisms: A case study of the South China Sea. Ecotoxicol. Environ. Saf. 2018, 163, 551-557. [CrossRef]

61. Briones, D.; Lazaro-Llanos, N. Omega-3 Fatty Acids versus Heavy Metals: A Quantitative Estimation of the Benefit-Risk Ratio for the Consumption of Commonly-Consumed Fish and Products in Metro Manila. KIMIKA 2015, 26, 40-51. [CrossRef]

62. Kerdthep, P.; Tongyonk, L.; Rojanapantip, L. Concentrations of cadmium and arsenic in seafood from Muang District, Rayong Province. J. Health Res. 2009, 23, 179-184.

63. Rajeshkumar, S.; Li, X. Bioaccumulation of heavy metals in fish species from the Meiliang Bay, Taihu Lake, China. Toxicol. Rep. 2018, 5, 288-295. [CrossRef] [PubMed]

64. Has-Schön, E.; Bogut, I.; Strelec, I. Heavy Metal Profile in Five Fish Species Included in Human Diet, Domiciled in the End Flow of River Neretva (Croatia). Arch. Environ. Contam. Toxicol. 2006, 50, 545-551. [CrossRef]

65. European Commission (EC). RASFF Portal Brussels, Belgium. Available online: https:/ /webgate.ec.europa.eu/rasff-window / portal/ ? event=searchForm\&cleanSearch=1 (accessed on 4 February 2020). 
66. Larsen, T.; Thilsted, S.H.; Kongsbak, K.; Hansen, M. Whole small fish as a rich calcium source. Br. J. Nutr. 2000, 83, 191-196. [CrossRef] [PubMed]

67. Roos, N.; Wahab, M.A.; Chamnan, C.; Thilsted, S.H. The role of fish in food-based strategies to combat vitamin A and mineral deficiencies in developing countries. J. Nutr. 2007, 137, 1106-1109. [CrossRef] [PubMed]

68. European Food Safety Authority (EFSA). Scientific Opinion on Lead in Food. EFSA J. 2010, 8, 1570.

69. Canli, M.; Atli, G. The relationships between heavy metal $(\mathrm{Cd}, \mathrm{Cr}, \mathrm{Cu}, \mathrm{Fe}, \mathrm{Pb}, \mathrm{Zn})$ levels and the size of six Mediterranean fish species. Environ. Pollut. 2003, 121, 129-136. [CrossRef]

70. Smith, L.C. The Use of Household Expenditure Surveys for the Assessment of Food Insecurity. In Measurement and Assessment of Food Deprivation and Undernutrition; FAO: Rome, Italy, 2003.

71. European Food Safety Authority (EFSA). Scientific Opinion on health benefits of seafood (fish and shellfish) consumption in relation to health risks associated with exposure to methylmercury. EFSA J. 2014, 12, 3761. [CrossRef]

72. Food and Agriculture Organization of the World (FAO)/Worhld Health Organization (WHO). Report of the Joint Expert Consultation on the Risks and Benefits of Fish Consumption. FAO Fish. Aquac. Rep. 2010, 978, 50. 